\title{
Grey Relational Entropy Calculation and Fractional Prediction of Water and Economy in the Beijing-Tianjin-Hebei Region
}

\author{
Lifeng Wu, ${ }^{1,2}$ Xiaorui Guo ${ }^{D}{ }^{1}$, and Yan Chen ${ }^{1}{ }^{1}$ \\ ${ }^{1}$ School of Management Engineering and Business, Hebei University of Engineering, Handan 056038, China \\ ${ }^{2}$ Hebei Key Laboratory of Intelligent Water Conservancy, Hebei University of Engineering, Handan 056038, China \\ Correspondence should be addressed to Xiaorui Guo; 943615471@qq.com
}

Received 19 June 2021; Revised 17 August 2021; Accepted 18 August 2021; Published 3 September 2021

Academic Editor: Firdous A. Shah

Copyright (c) 2021 Lifeng Wu et al. This is an open access article distributed under the Creative Commons Attribution License, which permits unrestricted use, distribution, and reproduction in any medium, provided the original work is properly cited.

The implementation of the Beijing-Tianjin-Hebei coordinated development strategy promotes the rapid development of the regional economy, but the consequent water shortage has become a major concern. How to optimize the allocation of water resources, promote the cooperation of water resources among various water-using departments, and maximize the water efficiency of the limited water resources in the region has become the main issue of research. Thus, this paper mainly studies the entropy value and the entropy difference of the grey relational entropy between water resources and economic systems. First, use the grey correlation entropy method to calculate the existing data to explore the relationship between the two systems, then use the $\operatorname{FGM}(1,1)$ model to predict the grey correlation entropy value of Beijing-Tianjin-Hebei in 2020-2024, and finally, calculate the entropy difference of the grey relation entropy for the region from 2015 to 2024 . The results show the following: (i) The connection between the water resources system and the economic system in the Beijing-Tianjin-Hebei region is poor, the entropy value between the two will continue to decrease from 2015 to 2024, and the degree of coordination has shown a decreasing trend. (ii) The entropy change value between the water resources system and the economic system in the Beijing-Tianjin-Hebei region reflects a gradual and orderly change trend. The research results can provide reasonable suggestions for improving the correlation between water resources and economic systems for government departments, local residents, and industrial enterprises in the BeijingTianjin-Hebei region, ultimately realizing the sustainable development of water resources and economic systems.

\section{Introduction}

As an important part of natural resources, water resources are not only a basic resource for human survival but also an economic resource for social development [1]. Therefore, it is one of the most important material foundations for the sustainable development of human beings, nature, and society [2]. The Third Plenary Session of the Eighteenth Central Committee of the Communist Party of China pointed out "Establish a monitoring and early warning mechanism for the carrying capacity of resources and the environment, and implement restrictive measures in areas where water and land resources." The 19th National Congress of the Communist Party of China put forward "Focus on solving the problems of imbalance and insufficiency in the development of water conservancy, and coordinate the solution of water resources, water environment, water ecology, and water disasters, so as to make the people's sense of gain, happiness and security more substantial" [3]. In March 2014, General Secretary Xi proposed a new era of water governance thinking of "water-saving priority, spatial balance, systematic governance, and both hands." It is required to regard the carrying capacity of the water environment and the water ecology as rigid constraints. Eventually realize the implementation of this kind of water control thinking into various tasks of reform, development, and stability [4]. It can be seen that promoting the rational use of water resources has become an important part of government work in recent years. The current water resources situation is not optimistic; take the Beijing-Tianjin-Hebei region as an example [5]. 
1.1. Lack of Water Resources in the Beijing-Tianjin-Hebei Region. "Beijing-Tianjin-Hebei" is the abbreviation for the two municipalities directly under the Central Government of Beijing and Tianjin and the three places of Hebei Province, with a territorial area of 218,000 square kilometers [6]. As of the end of 2019, the total population was 11.074 million. There is a serious water shortage in the three places. These data are from the 2020 China Statistical Yearbook. The total water resources in the Beijing-Tianjin-Hebei region are 14.619 billion cubic meters. The per capita water resources in Beijing area is 114.2 cubic meters per person, the per capita water resources in Tianjin area is 51.8 cubic meters per person, and the per capita water resources in Hebei area is 149.9 cubic meters per person.The Beijing-Tianjin-Hebei region carries $8 \%$ of the country's population, $11 \%$ of the total economic output and $1 \%$ of water resources. The per capita water resources are only 239 cubic meters, of which Hebei Province's per capita water amount of resources is only $1 / 14$ of the national average, Beijing's per capita water resources are only $1 / 20$ of the national average, and Tianjin's per capita water resources are only 1/40 of the national average. The situation of water resources in the Beijing-Tianjin-Hebei region is shown in Table 1.

\subsection{Irrational Water Resources Structure in the Beijing-} Tianjin-Hebei Region. The data in Table 2 shows that the total supply and water consumption of the Beijing-TianjinHebei region is 25.24 billion cubic meters, the total surface water is 10.41 billion cubic meters (accounting for $41.24 \%$ ), and the total groundwater is 11.58 billion cubic meters (accounting for $45.88 \%$ ). In terms of total water consumption, the rankings are agricultural water, domestic water, ecological water, and industrial water. The total agricultural water is 12.72 billion cubic meters, accounting for about $50.40 \%$. Agricultural water consumption is higher than the sum of industrial water, domestic water, and ecological water and even four times that of industrial water, indicating that the water use structure is unreasonable.

The rapid social and economic development and largescale population increase in the Beijing-Tianjin-Hebei region, the lack of water resources, the deterioration of the water environment, and the irrational distribution of water resources have become problems that restrict the sustainable development. This paper studies the correlation between the water resources system and the economic system of the BeijingTianjin-Hebei region, which helps to clarify the current degree of connection between the water resources and the economic system in the Beijing-Tianjin-Hebei region, so as to make reasonable suggestions for the subsequent coordinated development of the Beijing-Tianjin-Hebei region. Therefore, studying the correlation between the water resources system and the economic system in the Beijing-Tianjin-Hebei region has important research significance.

\section{Literature Review}

Since the Beijing-Tianjin-Hebei integration was proposed in 2015, the coordinated development between regions has become a topic of concern. Wei et al. introduced distance entropy and grey relational entropy, constructed a comprehensive similarity index to measure the similarity between equipment samples and equipment to be predicted, and established a weighted least squares method to predict equipment costs, indicating that the entropy theory that is based on the weighted regression calculation model has high prediction accuracy and stability [7]. Li et al. used grey correlation entropy to analyze the influence of cement concrete pore structure evolution characteristics on strength [8]. Chen et al. used grey relational entropy and dissipative structure theory to analyze the impact of digital economy development on industrial structure upgrading, explored the internal mechanism and basic path of the digital economy to promote industrial structure upgrading, and used the grey relational entropy model to test empirically the relationship between the digital economy and my country's industrial structure discussed, and finally, feasible suggestions were put forward [9]. Zhao et al. proposed a grey entropy correlation algorithm based on the combination of grey correlation algorithm and entropy weight method and studied the correlation coefficient between the macrofactors of the national economy and the volume of road freight and cargo turnover [10]. Zhang et al. quantitatively evaluated the influence of multiple related factors on the performance of maximum power point tracking control based on the grey correlation theory [11]. Zhu et al. analyzed the influence of various indexes of high viscosity modified asphalt on the antirutting ability and water damage ability of drainage asphalt mixture at high temperature by grey relation entropy analysis method [12]. Li et al. used the grey relation entropy method to study the order of China's emerging industries and the optimization and upgrading of China's industrial structure [13].

The grey system theory puts forward the viewpoint of grey relational analysis of each subsystem; the purpose is to find the numerical relationship between the subsystems (or factors) in the system through a certain method. Grey relational analysis is one of the important contents of grey system theory, which is widely used in the research fields of society, economy, agriculture, ecology, and so on. He calculated the correlation between PM2.5 concentration and influencing factors using the grey correlation model and analyzed the relationship between the main influencing index factors and the spatial distribution of PM2.5 [14]. Zhang et al. quantitatively evaluated the influence of various related factors on the maximum power point tracking control performance of wind turbines based on the grey relational theory [11]. Yin et al. conducted a questionnaire survey on the cognition of medical service prices in various parts of my country and then analyzed the data obtained from the questionnaire survey using the theory of grey relational analysis to analyze the cognition of medical service prices by medical personnel in various parts of our country [15]. Liu et al. proposed the application of grey modeling in the analysis of thermal spraying process parameters in a lowdata environment. In the above-mentioned research, scholars have made various explorations and achieved fruitful results. In response to problems in different fields, scholars have made improvements on the basis of traditional 
Table 1: Water resources in the Beijing-Tianjin-Hebei region in 2019.

\begin{tabular}{lcccc}
\hline Region & $\begin{array}{c}\text { Total water resources (100 } \\
\text { million cubic meters) }\end{array}$ & $\begin{array}{c}\text { Surface water resources (100 } \\
\text { million cubic meters) }\end{array}$ & $\begin{array}{c}\text { Groundwater resources (100 } \\
\text { million cubic meters) }\end{array}$ & $\begin{array}{c}\text { Water resources per capita } \\
\text { (cubic meters/person) }\end{array}$ \\
\hline Beijing & 24.6 & 8.6 & 24.7 & 114.2 \\
Tianjin & 8.09 & 5.12 & 4.16 & 51.8 \\
Hebei & 113.5 & 51.37 & 97.86 & 149.9 \\
Total & 146.19 & 65.09 & 126.72 & \\
\hline
\end{tabular}

Data source: China Statistical Yearbook 2020.

TABle 2: Water use of water resources in the Beijing-Tianjin-Hebei region.

\begin{tabular}{|c|c|c|c|c|c|c|c|c|}
\hline Region & $\begin{array}{l}\text { Total water } \\
\text { supply (100 } \\
\text { million } \\
\text { cubic } \\
\text { meters) }\end{array}$ & $\begin{array}{c}\text { Surface } \\
\text { water }(100 \\
\text { million } \\
\text { cubic } \\
\text { meters) }\end{array}$ & $\begin{array}{l}\text { Groundwater } \\
\text { (100 million } \\
\text { cubic meters) }\end{array}$ & $\begin{array}{c}\text { Total water } \\
\text { consumption } \\
(100 \text { million cubic } \\
\text { meters })\end{array}$ & $\begin{array}{l}\text { Agricultural } \\
\text { water (100 } \\
\text { million cubic } \\
\text { meters) }\end{array}$ & $\begin{array}{l}\text { Industrial } \\
\text { water (100 } \\
\text { million cubic } \\
\text { meters) }\end{array}$ & $\begin{array}{l}\text { Domestic } \\
\text { water (100 } \\
\text { million cubic } \\
\text { meters) }\end{array}$ & $\begin{array}{c}\text { Ecological } \\
\text { water (100 } \\
\text { million cubic } \\
\text { meters) }\end{array}$ \\
\hline Beijing & 41.7 & 6.6 & 15.5 & 41.7 & 3.7 & 3.3 & 18.7 & 16 \\
\hline Tianjin & 28.4 & 19.2 & 3.9 & 28.4 & 9.2 & 5.5 & 7.5 & 6.2 \\
\hline Hebei & 182.3 & 78.3 & 96.4 & 182.3 & 114.3 & 18.8 & 27 & 22.1 \\
\hline Total & 252.4 & 104.1 & 115.8 & 252.4 & 127.2 & 27.6 & 53.2 & 44.3 \\
\hline
\end{tabular}

Data source: China Statistical Yearbook 2020.

grey relational analysis methods to make the calculation results more scientific and reasonable [16]. Shen et al. applied improved grey relational analysis to the Danjiangkou basin surface water environmental quality assessment study, considering the interval form of the water quality assessment standard, which is more objective than judging water quality categories based on critical values. In addition, the dimensionless method has been adjusted, and the "centralized" method is adopted, which makes the calculation results easier to distinguish than the original method, and the physical meaning is clearer [17]. Wang et al. proposed a voltage sag source identification method based on improved grey relational analysis to accurately identify various sag sources in the power grid. By assigning a weight coefficient to each feature response, the inherent characteristics of different sink sources are highlighted, and the recognition accuracy is improved [18]. Based on the above literature, we can understand that scholars have improved the traditional grey correlation model by assigning index weights, adjusting nondimensional methods, and using different standards to express the similarity of sequence curves. Compared with traditional grey relational models, these improved grey relational analyses are more suitable for research in different fields.

Since Professor Deng Julong founded the grey system theory in 1982, the grey prediction model has become an important part of the grey system theory, so it has received strong attention from many scholars. Research in different fields has promoted the further development and improvement of the grey forecasting model, which facilitates its better adaptation to various fields [19]. Wu introduced the idea of fractional order into the grey sequence operator and grey prediction model [20]. In a study by Meng et al., based on the subtractive and fractional accumulative generating operator, a discrete grey prediction model of the fractional operator was established, which greatly improved the accuracy of prediction [21]. The discharge of wastewater, chemical oxygen demand, and ammonia nitrogen from wastewater in 31 cities of China are predicted by the fractional grey model [22]. Cui proposes a new type of grey prediction model, which improves the prediction performance of the grey prediction model and expands its scope of application [23]. Wu et al. used the fractional GM $(1,1)$ model to predict the concentration of air pollutants and the number of days with good air in the Beijing-Tianjin-Hebei region and proposed a fractional cumulative Holt-Winters model to predict the ambient air quality index of Shijiazhuang and Handan $[24,25]$. Li et al. established the $\mathrm{GM}(1,1)$ model and RBF neural network model, respectively, to predict the urban industrial land demand of the Beijing-Tianjin-Hebei urban agglomeration and compare the prediction results with Beijing, Tianjin, and Hebei; the actual value of urban industrial land in 11 prefecture-level cities in the province was compared to determine a reasonable prediction model $[26,27]$.

Particle swarm optimization algorithm is a new type of parallel metaheuristic algorithm first proposed by American psychologist Kennedy and electrical engineer Eberhart in 1995. The algorithm is to simulate the mutual cooperation mechanism in the foraging behavior of birds, fish, and other creatures in nature to find the optimal solution to the problem. Because of its simple structure, fewer parameters to be adjusted, less professional knowledge involved, and easy implementation, most scholars apply it to many practical problems, including multiobjective optimization problems, nonlinear integer and mixed integer constrained optimization problems, and signal processing neural network training [28]. Li et al. established the GM $(1,1)$ model and the RBF neural network model, respectively, to predict the urban industrial land demand of the Beijing-Tianjin-Hebei urban agglomeration. The comparison found that the radial basis function neural network model is a more reasonable 
urban industrial land prediction model, and then the prediction results of the radial basis neural network model are used to combine the expected indicators of the planning target year of Beijing, Tianjin, and the 11 prefecture-level cities in Hebei Province (2006-2020) to determine the remaining available time for urban industrial land [26]. Milad et al. present a feature selection method in multiobjective particle swarm optimization space. For this task, a novel particle ranking is proposed based on particle distance from dominated and nondominated particles and then used for feature rank computation. Position and velocity of particles are updated by a new update rule relies in feature ranks encoded in a vector [29]. Nipun et al. present a method to localize a source in complex urban environments using particle swarm optimization (PSO); it can be used to inform first responder or create a tool that can be implemented on UAV to locate a contaminant source [30].

Based on the research content of the above scholars, this paper uses the grey relational entropy model and the $\operatorname{FGM}(1,1)$ model to calculate the 2015-2019 data in the Beijing-Tianjin-Hebei region.

\section{Data and Materials}

3.1. Study Area. Since the integration of the Beijing-TianjinHebei region, it will inevitably have an indispensable impact on the income level, the number of residents, and the use of water resources in the three regions. As a major industrial province, Hebei Province has achieved alleviation of environmental problems by adjusting the industrial structure. However, the adjustment of the industrial structure will inevitably cause changes in the economy and water resources. At the same time, the development of BeijingTianjin-Hebei integration will increase the frequency of personnel movement in Beijing, Hebei, and Tianjin, which will affect the changes in the tertiary industry and the use of water resources.

Therefore, this article selects the water resources system and economic system of the Beijing-Tianjin-Hebei region from 2015 to 2019 as the research content. The total water supply, per capita water consumption, agricultural water consumption, industrial water consumption, domestic water consumption, ecological water consumption, and per capita water resources are regarded as the total water resources system. The total water supply is the total water supply of the entire city, the per capita water consumption and the per capita water resources are the amount of water used and owned by the population, and the water consumption of agriculture, industry, life, and ecology is the water consumption of a single field.

Since this article wants to investigate the connection between water resources and economic systems, it is necessary to subdivide the economic systems and classify them according to the "Regulations on the Classification of Three Industries (2012)" revised by the National Bureau of Statistics in 2018. Primary industry refers to agriculture, forestry, animal husbandry, and fishery (excluding agriculture, forestry, animal husbandry, fishery, and auxiliary activities). The secondary industry refers to the mining industry (excluding mining professional and auxiliary activities), manufacturing (excluding metal products, machinery, and equipment repair industries), electricity, heat, gas and water production and supply, and construction. The tertiary industry is the service industry, which refers to industries other than the primary industry and the secondary industry. Therefore, the added value of the primary industry, industrial added value, construction added value, tertiary industry added value, and population in the Beijing-TianjinHebei region are regarded as the economic system. The original data of the water resources system and economic system of the Beijing-Tianjin-Hebei region come from the statistical yearbooks and statistical bulletins of each province. The detailed research indicators in the water resourceseconomic system are shown in Table 3.

3.2. Data Collection. The detailed data of the water-economic system indicators in the Beijing-Tianjin-Hebei region are shown in Tables 4-6. Table 4 data come from the official website of the Beijing Municipal Bureau of Statistics at https://tjj.beijing.gov.cn/tjsj_31433/tjnj_31441/bjtjnj_31442/ , Table 5 data come from the official website of the Tianjin Bureau of Statistics at https://stats.tj.gov.cn/tjsj_52032/tjnj/, and Table 6 data come from the Hebei Provincial Bureau of Statistics at https://tjj.hebei.gov.cn/hetj/tjsj/jjnj/. The data that are not in the above three official websites comes from https://www.stats.gov.cn/.

\section{Model Introduction}

Specifically, in order to quantify the relationship between water-economic systems [31], it is necessary to calculate the grey correlation entropy in the grey correlation [26]. Firstly, after calculating the entropy value through grey correlation, the particle swarm algorithm is used to calculate the order with the smallest error, and the order calculated by the particle swarm is substituted into the fractional-order model. After calculation, the predicted entropy value of water and economic system is obtained. Finally, calculate the entropy difference between the water resources system and the economic system in 2015-2024.

4.1. Grey Relational Entropy Model. Grey relational entropy is a method that combines the grey system theory and the entropy change model. It is a method produced by correcting the local point association tendency and the average loss in the calculation process of the grey relation. Generally, when the grey correlation method is used to determine the degree of correlation, the average value method is used, but the use of this average value method will cause two major problems. One is that the overall degree of relevance tends to be larger. The second is the lack of extreme information data [32]. Therefore, this paper uses the index extreme value method to process the data. Specific steps are as follows:

(1) Determine the reference index and comparison index 
TABLe 3: Water resources-economic system.

\begin{tabular}{lc}
\hline & Total water supply (100 million cubic meters) \\
\hline Water resources system & Water consumption per capita (cubic meters/person) \\
& Agricultural water consumption (100 million cubic meters) \\
& Industrial water consumption (100 million cubic meters) \\
& Domestic water consumption (100 million cubic meters) \\
& Ecological water consumption (100 million cubic meters) \\
Economic system & Water resources per capita (cubic meters/person) \\
& Added value of primary industry (100 million yuan) \\
& Industrial added value (100 million yuan) \\
& Added value of construction industry (100 million yuan) \\
& Added value of tertiary industry (100 million yuan) \\
& Permanent residents (10,000 people)
\end{tabular}

TABle 4: Original data in Beijing.

\begin{tabular}{|c|c|c|c|c|c|}
\hline & 2015 & 2016 & 2017 & 2018 & 2019 \\
\hline Added value of primary industry (100 million yuan) & 140.21 & 129.79 & 120.42 & 118.69 & 113.69 \\
\hline Industrial added value (100 million yuan) & 3710.88 & 3635.5 & 3885.9 & 4139.9 & 4241.1 \\
\hline Added value of construction industry (100 million yuan) & 961.86 & 1074.5 & 1210.9 & 1387.8 & 1513.67 \\
\hline Added value of tertiary industry (100 million yuan) & 18331.74 & 20594.9 & 22567.76 & 24553.64 & 29542.53 \\
\hline Permanent residents $(10,000$ people $)$ & 2170.5 & 2172.9 & 2170.7 & 2154.2 & 2153.6 \\
\hline Total water supply (100 million cubic meters) & 38.2 & 38.8 & 39.5 & 39.3 & 41.7 \\
\hline Water consumption per capita (cubic meters/person) & 176.8 & 178.6 & 181.9 & 181.7 & 193.6 \\
\hline Agricultural water consumption (100 million cubic meters) & 6.4 & 6 & 5.1 & 4.2 & 3.7 \\
\hline Industrial water consumption (100 million cubic meters) & 3.8 & 3.8 & 3.5 & 3.3 & 3.3 \\
\hline Domestic water consumption (100 million cubic meters) & 17.5 & 17.8 & 18.3 & 18.4 & 18.7 \\
\hline Ecological water consumption (100 million cubic meters) & 10.4 & 11.1 & 12.7 & 13.4 & 16 \\
\hline Water resources per capita (cubic meters/person) & 124 & 161.6 & 137.2 & 164.2 & 114.2 \\
\hline
\end{tabular}

Table 5: Original data in Tianjin.

\begin{tabular}{|c|c|c|c|c|c|}
\hline & 2015 & 2016 & 2017 & 2018 & 2019 \\
\hline Added value of primary industry (100 million yuan) & 208.82 & 220.22 & 168.96 & 172.71 & 185.23 \\
\hline Industrial added value (100 million yuan) & 6982.66 & 6805.13 & 6863.98 & 6962.71 & 4394.27 \\
\hline Added value of construction industry (100 million yuan) & 740.31 & 786.89 & 745.66 & 621.1348 & 693.76 \\
\hline Added value of tertiary industry (100 million yuan) & 8625.15 & 10093.82 & 10786.64 & 11027.12 & 8949.87 \\
\hline Permanent residents $(10,000$ people $)$ & 1546.95 & 1562.12 & 1556.87 & 1559.6 & 1561.83 \\
\hline Total water supply (100 million cubic meters) & 25.675 & 27.2307 & 27.4905 & 28.4235 & 28.4483 \\
\hline Water consumption per capita (cubic meters/person) & 167.8 & 175 & 176.3 & 182.2 & 181.9 \\
\hline Agricultural water consumption (100 million cubic meters) & 12.5 & 12 & 10.7 & 10 & 9.2 \\
\hline Industrial water consumption (100 million cubic meters) & 5.3 & 5.5 & 5.5 & 5.4 & 5.5 \\
\hline Domestic water consumption (100 million cubic meters) & 4.9 & 5.6 & 6.1 & 7.4 & 7.5 \\
\hline Ecological water consumption (100 million cubic meters) & 2.9 & 4.1 & 5.2 & 5.6 & 6.2 \\
\hline Water resources per capita (cubic meters/person) & 124.84 & 121.12 & 83.6 & 112.72 & 51.8 \\
\hline
\end{tabular}

In this paper, each evaluation index in the economic system of each province is used as a reference index $X_{0}$; per capita water consumption, agricultural water consumption, industrial water consumption, domestic water consumption, ecological water consumption, and per capita water resource possession under the water resources system are used as comparative indicators $X_{i}$.

(2) Dimensionless data

$X_{0}$ and $X_{i}$ are the elements in the two systems respectively, and the observation series of the two in the same year are $X_{0}=\left\{x_{0}(1), x_{0}(2), \ldots, x_{0}(n)\right\}$ and $X_{i}=\left\{x_{i}(1), x_{i}(2), \ldots, x_{i}(n)\right\}$, respectively.
Dimensionless processing of time series

$$
\begin{aligned}
& X_{0}^{\prime}(t)=\frac{\left(X_{0}(t)-\min X_{0}\right)}{\left(\max X_{0}-\min X_{0}\right)} \\
& X_{i}^{\prime}(t)=\frac{\left(X_{i}(t)-\min X_{i}\right)}{\left(\max X_{i}-\min X_{i}\right)}
\end{aligned}
$$

(3) Calculate the grey correlation coefficient

The degree of grey correlation is to compare the degree of fit of the development trend between two variables and obtain the correlation coefficient by calculating the correlation between each node, time, 
Table 6: Original data in Hebei.

\begin{tabular}{|c|c|c|c|c|c|}
\hline & 2015 & 2016 & 2017 & 2018 & 2019 \\
\hline Added value of primary industry (100 million yuan) & 3439.45 & 3492.81 & 3129.98 & 3338 & 3518.44 \\
\hline Industrial added value (100 million yuan) & 12626.17 & 13387.46 & 13757.84 & 13698 & 11503.03 \\
\hline Added value of construction industry (100 million yuan) & 1780.49 & 1885.27 & 2109.03 & 2362.7 & 2129.89 \\
\hline Added value of tertiary industry (100 million yuan) & 11979.79 & 13320.71 & 15040.13 & 16632.21 & 17988.82 \\
\hline Permanent residents $(10,000$ people $)$ & 7424.92 & 7470.05 & 7519.52 & 7556.3 & 7591.97 \\
\hline Total water supply (100 million cubic meters) & 187.2 & 182.6 & 181.6 & 182.4 & 182.29 \\
\hline Water consumption per capita (cubic meters/person) & 252.8 & 245.2 & 242.3 & 242 & 240.7 \\
\hline Agricultural water consumption (100 million cubic meters) & 135.3 & 128 & 126.1 & 121.1 & 114.3 \\
\hline Industrial water consumption (100 million cubic meters) & 22.5 & 21.9 & 20.3 & 19.1 & 18.8 \\
\hline Domestic water consumption (100 million cubic meters) & 24.4 & 25.9 & 27 & 27.8 & 27 \\
\hline Ecological water consumption (100 million cubic meters) & 5 & 6.7 & 8.2 & 14.5 & 22.1 \\
\hline Water resources per capita (cubic meters/person) & 182.5 & 279.7 & 184.5 & 217.7 & 149.9 \\
\hline
\end{tabular}

or indicator between the two variables. These correlation coefficients are combined to obtain the correlation degree between the two variables. The greater the degree of association, the stronger the association between the two objects, and vice versa.

After the nondimensional processing of the original data, the grey correlation analysis method is used to calculate the grey correlation between them. The grey correlation coefficient can reflect the degree of correlation between the sequences. Among them, $\rho$ is the resolution coefficient, $0<\rho<1$. Taking into account the possible errors of the survey data, based on previous studies, take $\rho=0.5$.

$$
\begin{aligned}
r\left[X_{0}^{\prime}(t), X_{i}^{\prime}(t)\right] & =\frac{\max _{i} \max _{t}\left|X_{0}^{\prime}(t)-X_{i}^{\prime}(t)\right|+\rho \max _{i} \max _{t}\left|X_{0}^{\prime}(t)-X_{i}^{\prime}(t)\right|}{\left|X_{0}^{\prime}(t)-X_{i}^{\prime}(t)\right|+\rho \max _{i} \max _{t}\left|X_{0}^{\prime}(t)-X_{i}^{\prime}(t)\right|}, \\
r\left(X_{0}, X_{i}\right) & =\frac{1}{n} \sum_{t=1}^{n} r\left(x_{o}(t), x_{i}(t)\right) .
\end{aligned}
$$

Among them, $r\left(X_{0}, X_{i}\right)$ satisfies the four axioms of grey correlation, which is called $X_{0}$ and $X_{i}$. And $r\left(X_{0}, X_{i}\right)$ is the grey correlation degree.

(4) Calculate the grey correlation density value

Mapping the grey correlation coefficient, the resulting mapping value is the distribution density value $p_{i}(t)$ :

$$
\begin{aligned}
& \text { Map: } r_{i}(t) \longrightarrow p_{i}(t), \\
& p_{i}(t)=\frac{r_{i}(t)}{\sum_{t=1}^{n} r_{i}(t)}
\end{aligned}
$$

where $p_{i}>0$ and $\sum_{t=1}^{n} p_{i}(t)=1$.

(5) Calculate grey relation entropy and grey relation entropy change

On the basis of the distribution mapping, calculate the grey correlation entropy $S(t)$ and the grey correlation entropy change $\Delta S(t)$ :

$$
\begin{aligned}
S(t) & =-\sum_{i=1}^{m} p_{i}(t) \ln p_{i}(t), \\
\Delta S(t) & =S(t)-S(t-1) .
\end{aligned}
$$

(6) Grey relational entropy of a single indicator of water resources system and economic system

On the basis of the distribution mapping, the grey relational entropy coordinated by an indicator in the economic system and all indicators in the water resources system can be expressed as

$$
H\left(r_{i}(t)\right)=-\sum_{h=1}^{n} P_{h} \ln P_{h} .
$$

According to the grey relation entropy theorem, the greater the grey relation entropy, the stronger the coordination. When the entropy becomes a negative value, it means that the system is evolving in a benign and orderly direction. When the entropy becomes a positive value, it means that the disorder of the system increases. One thing that needs to be pointed out is that the grey relational entropy model mainly tests the relative coordination between the index systems, that is, whether the coordination situation of this year has been improved compared with the previous year. Therefore, based on the comparison between a certain grey relational entropy value and the base period reference value, the overall 
coordination status can be analyzed and judged according to the change of the entropy value [33].

4.2. Forecasting Model. In this paper, the fractional-order model (abbreviated as) is used to predict the data. Using the fractional-order model to predict can weaken the randomness of the original sequence, make the grey prediction model less disturbing and incorporate the principle of new information first [34].

Step 1. Set the original nonnegative sequence to $X^{(0)}=\left\{x^{(0)}(1), x^{(0)}(2), \ldots, x^{(0)}(n)\right\}$, and pass

$$
x^{(r)}(k)=\sum_{i=1}^{k} C_{k-i+r-1}^{k-i} x^{(0)}(i) .
$$

The cumulative sequence of order $r$ of $X^{(0)}$ can be obtained, which is $X^{(r)}=\left\{x^{(r)}(1), x^{(r)}(2), \ldots, x^{(r)}(n)\right\}$.

Stipulate $C_{r-1}^{0}=1, C_{k}^{k+1}=0, C_{k-i+r-1}^{k-} i=(((k-i+r-1)$ $(k-i+r-2), \ldots,(r+1) r) / 2 a)$.

Generate the background value $x$ for the r-order cumulative sequence and calculate

$$
Z^{(r)}(k)=\frac{1}{2}\left(x^{(r)}(k)+x^{(r)}(k-1)\right)
$$

Step 2. In the $r$ order accumulative sequence of the grey model, the whitening differential equation is

$$
\frac{\mathrm{d} x^{(r)}(k)}{\mathrm{d} t}+a x^{(r)}(k)=b .
$$

Among them, $a$ is the development coefficient, and $b$ is the grey effect.

The time response function can be obtained as

$$
x^{(r)}(k+1)=\left(x^{(0)}(1)-\frac{b}{a}\right) e^{-a k}+\frac{b}{a} \text {. }
$$

Step 3. Since the least squares estimation minimizes the sum of squared errors, the least squares method is used to obtain the parameter

$$
\left[\begin{array}{l}
\widehat{a} \\
\widehat{b}
\end{array}\right]=\left(B^{T} B\right)^{-1} B^{T} Y .
$$

Among them,

$$
\begin{aligned}
& B=\left(\begin{array}{cc}
-\frac{1}{2}\left(x^{(r)}(1)+x^{(r)}(2)\right) & 1 \\
-\frac{1}{2}\left(x^{(r)}(2)+x^{(r)}(3)\right) & 1 \\
\vdots & \vdots \\
-\frac{1}{2}\left(x^{(r)}(n-1)+x^{(r)}(n)\right) & 1
\end{array}\right) \text {, } \\
& Y=\left[\begin{array}{c}
x^{(r)}(2)-x^{(r)}(1) \\
x^{(r)}(2)-x^{(r)}(1) \\
\vdots \\
x^{(r)}(n)-x^{(r)}(n-1)
\end{array}\right] .
\end{aligned}
$$

Step 4. Make $\widehat{a}$ and $\widehat{b}$ lead the time response function

$$
\widehat{x}^{(r)}(k+1)=\left(x^{(0)}(1)-\frac{\widehat{b}}{\widehat{a}}\right) e^{-\widehat{a} k}+\frac{\widehat{b}}{\widehat{a}},
$$

where $\hat{x}^{(r)}(k+1)$ is the fitted value at time $k+1$, which results in the sequence

$$
\widehat{X}^{(r)}=\left\{\widehat{x}^{(r)}(1), \widehat{x}^{(r)}(2), \ldots, \widehat{x}^{(r)}(n), \ldots,\right\} .
$$

Step 5. Do $r$ steps of cumulative subtraction on $\widehat{X}^{(r)}=\left\{\widehat{x}^{(r)}(1), \hat{x}^{(r)}(2), \ldots, \hat{x}^{(r)}(n), \ldots,\right\}$ to get

$$
\begin{aligned}
\widehat{X}^{(0)} & =\alpha^{(r)} \widehat{X}^{(r)} \\
& =\left\{\alpha^{(1)} \widehat{x}^{(r)(1-r)}(1), \alpha^{(1)} \widehat{x}^{(r)(1-r)}(2), \ldots, \alpha^{(1)} \widehat{x}^{(r)(1-r)}(n), \alpha^{(1)} \widehat{x}^{(r)(1-r)}(n+1), \ldots,\right\},
\end{aligned}
$$

where $\alpha^{(1)} \hat{x}^{(r)(1-r)}(k)=\hat{x}^{(r)(1-r)}(k)-\hat{x}^{(r)(1-r)}(k-1)$.

From this, the fitted value of the original data can be obtained $\widehat{x}^{(0)}(1), \widehat{x}^{(0)}(2), \ldots, \widehat{x}^{(0)}(n)$, and the predicted value is $\hat{x}^{(0)}(n+1), \hat{x}^{(0)}(n+2), \ldots$.

Since the fractional order is used to predict the data, the value of $r$ is particularly important. The value of $r$ is different, and the model results are also different. The main research idea for finding the optimal value of $r$ is to minimize the error of the prediction model. The model error is generally expressed by the absolute value of the average relative error (MAPE). In this paper, we use the PSO model to find the optimal order. The particle swarm algorithm can find the minimum adaptation threshold or the maximum number of iterations in a short time and under certain conditions.

$$
\text { MAPE }=\frac{1}{n} \sum_{i=1}^{n}\left|\frac{\widehat{x}^{(0)}(k)-x^{(0)}(k)}{x^{(0)}(k)}\right| \times 100 \% .
$$




\section{Model Solving and Data Analysis}

5.1. Calculation and Analysis of Existing Data. Using the water resources system data and economic system data of the Beijing-Tianjin-Hebei region from 2015 to 2019 as evaluation indicators, the grey correlation calculation between the two systems is performed. And then grey correlation entropy calculations are performed on these data to determine which factors have a greater impact on the water resources system, the annual entropy value and entropy change are calculated, and the value of the entropy change is used to judge whether there is an improvement. Finally, use $\operatorname{FGM}(1,1)$ to predict the data for the next five years.

5.1.1. Dimensionless Values. The water resources system and the economic system of the Beijing-Tianjin-Hebei region from 2015 to 2019 are numerically used formulas for nondimensional processing.

\subsubsection{Grey Correlation Degree in the Beijing-Tianjin-Hebei} Region. By calculating the grey correlation degree and the grey correlation entropy value between the water resources system and the economic system in the Beijing-TianjinHebei region. The grey correlation degree of the water resources-economic system is shown in Figures 1-3.

Regarding Figure 1, from the point of view of the added value of the primary industry, the high correlation coefficients are agricultural water and industrial water, with a value between 0.8 and 0.9 . From the perspective of industrial added value, the correlation with the total water supply is very high, about 0.8 , but the grey correlation coefficient with industrial water is only 0.48 . The correlation between the added value of the tertiary industry and the total water supply and ecological water consumption is close to 0.9 or more, and the relationship between the added value of the tertiary industry and the per capita water consumption and domestic water consumption is also close to 0.8 .

As shown in Figure 2, the correlation between the added value of the primary industry and the added value of agricultural water consumption in Tianjin is about 0.7 , but the correlation with the total water supply is only 0.43 . Although the correlation between industrial added value and total water supply reaches 0.57 , there are still problems with the correlation with other evaluation indicators. The correlation between the added value of the tertiary industry and per capita water resources is only 0.65 , while the correlation with total water supply, per capita water consumption, and domestic water consumption are all above 0.75 . The correlation between the permanent population and the water resources index is relatively good, but relatively speaking, the correlation between the permanent population and the per capita water resources is still lacking compared with other indicators.

In Figure 3, the correlation degree between the added value of the primary industry and agricultural water consumption is only 0.57 , and the correlation degree between the value added of the primary industry and the total water supply is only 0.61 . The degree of correlation between

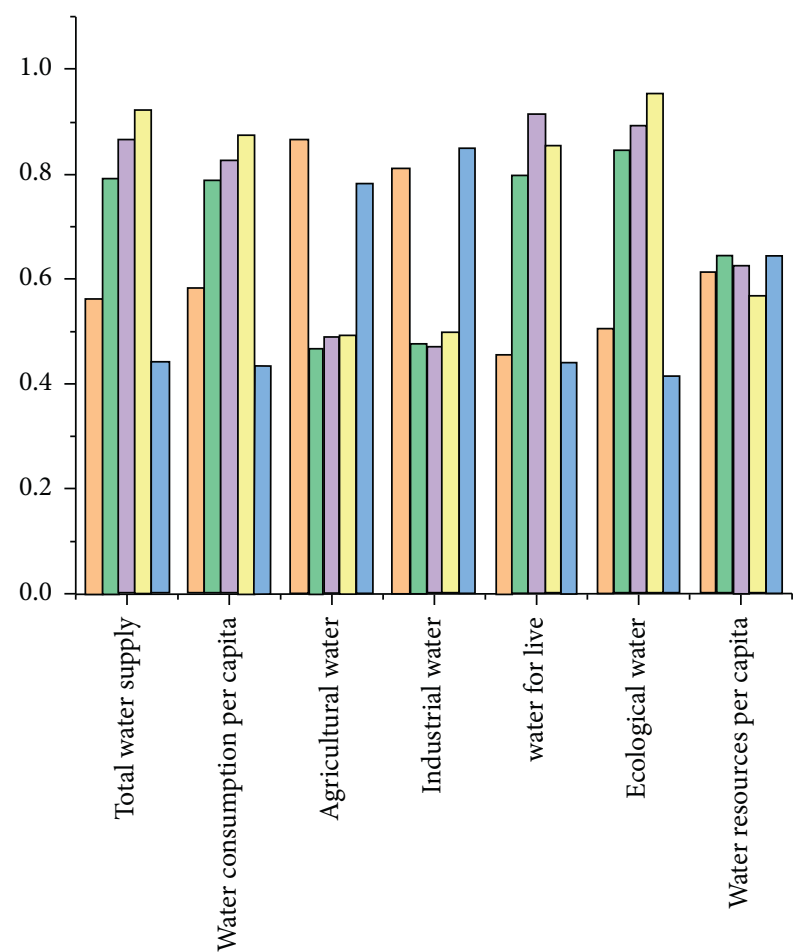

Added value of primary industry Industrial added value Added value of construction industry Added value of tertiary industry permanent residents

FIgURE 1: Grey relational degree between Beijing water resources system and economic system.

industrial added value and total water supply is only 0.49 , and the degree of correlation with industrial water use is 0.66 . The correlation between the added value of the construction industry and the total water supply is only 0.54 , and the correlation with industrial water use is 0.46 . The correlation degree between the added value of the tertiary industry and the total water supply is only 0.51 , which is relatively far from the correlation degree of other water resources indicators. The correlation degree between the permanent population and the total water supply is 0.51 , the correlation degree with per capita water consumption is 0.49 , and the correlation degree with per capita water resources is 0.55 , but the correlation degree with domestic water consumption is 0.75 .

In short, from the perspective of Beijing-Tianjin-Hebei as a whole, the correlation between the indicators in the economic system and the total water supply is relatively low, and most of them are in the range of $0.4-0.5$. In the three regions, the correlation between the value added of the primary industry and agricultural water use is relatively good, and the correlation between the value added of industry and construction industry and industrial water use is very poor, all within the range of $0.40-0.61$. The correlation between the added value of the tertiary industry and the permanent population and the water resources system is 


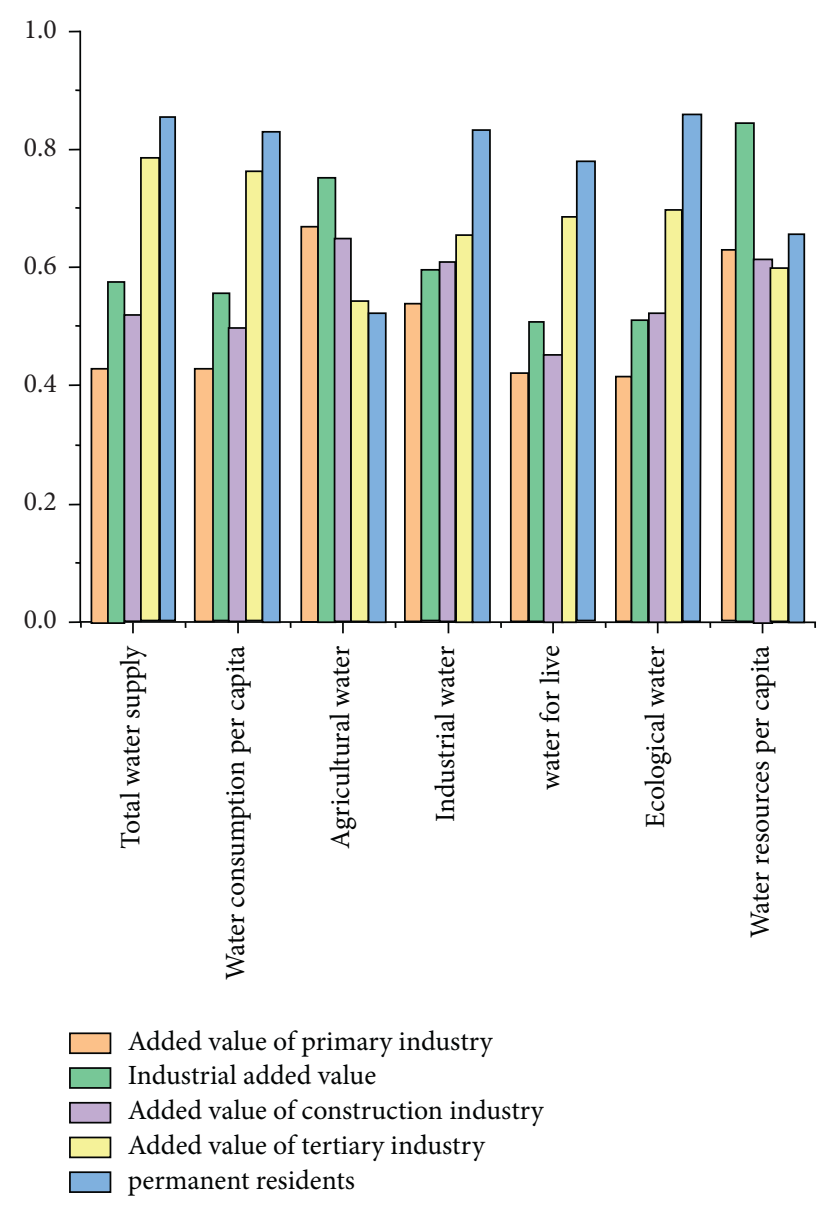

Figure 2: Grey relational degree between Tianjin water resources system and economic system.

relatively good. The size of the entropy value represents the coordination degree relationship between the two, the larger the entropy value, the better the coordination degree, the smaller the entropy value, the worse the coordination degree.

\subsection{Entropy Sorting of the Water Resources System. From} Table 7, the ranking between the added value of the primary industry and the agricultural water consumption is the first, but the values added of the primary industry and total water supply rank only sixth. The ranking between industrial added value and industrial water consumption turned out to be seventh, and the ranking between total water supply and industrial added value was only fourth. The entropy ranking between the added value of the construction industry and the amount of industrial water consumption turned out to be seventh. It shows that there is a big problem between these two systems.

Looking at the grey correlation entropy value ranking between the two systems from Table 8 , it is found that the total amount of water supply in Beijing and the added value of several industries in the economic system rank fourth and fifth. The ranking of agricultural water consumption is only

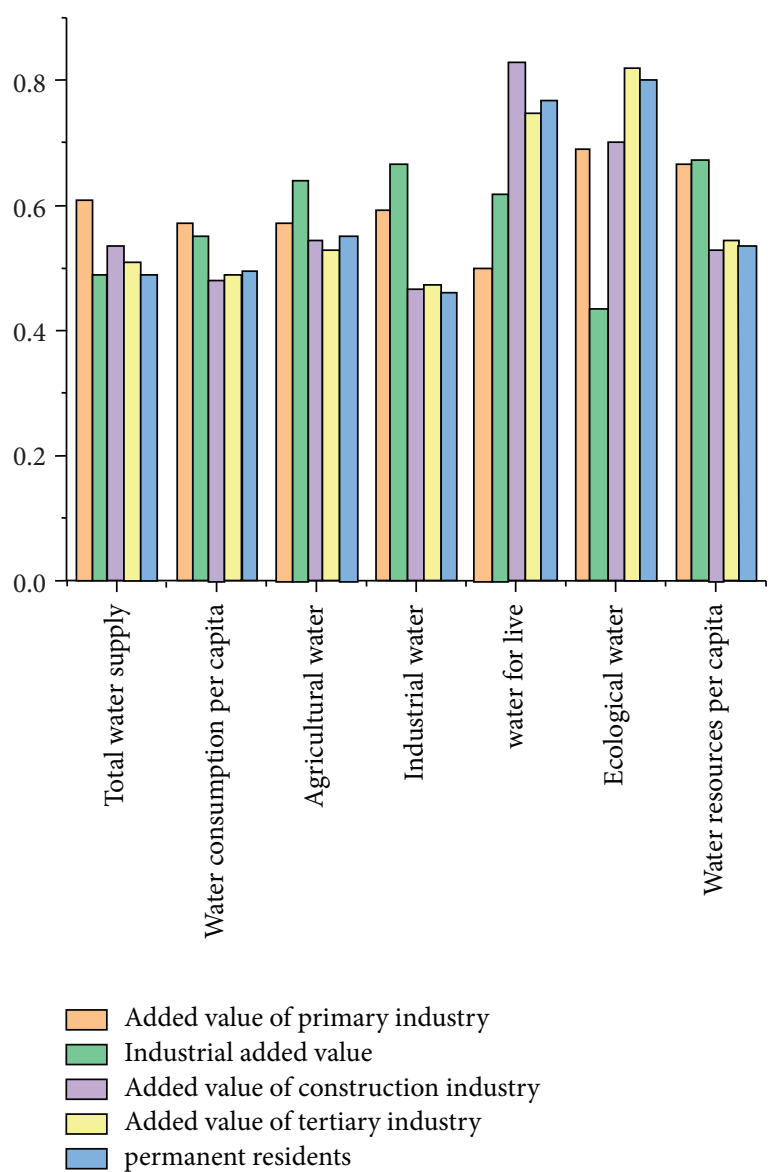

Figure 3: Grey relational degree between Hebei water resources system and economic system.

fourth, and the ranking of industrial added value and industrial water consumption turned out to be seventh.

From the grey correlation entropy in Table 9, the coordination degree between the added value of the primary industry and the total water supply is low, and the coordination degree between the industrial added value and industrial water consumption is low, both ranking fifth. Similarly, we found that the correlation entropy ranking between the added value of the construction industry and industrial water consumption turned out to be seventh, and the entire secondary industry had little relationship with industrial water consumption. The added value of the tertiary industry has a high degree of coordination with domestic water, but it has a low degree of coordination with the total water supply.

\subsection{Prediction of Entropy in the Beijing-Tianjin-Hebei Region}

5.3.1. Grey Relational Entropy of the Economic System. Tables 10-12 shows the grey correlation entropy value between the overall economic system and water resources in the Beijing-Tianjin-Hebei region. Table 10 shows the specific values in Beijing, Table 11 shows the specific values in Tianjin, and Table 12 shows the specific values in Hebei. 
TABLE 7: Grey relation entropy sorting between the Beijing water resources system and economic system.

\begin{tabular}{|c|c|c|c|c|c|}
\hline & $\begin{array}{l}\text { Added value of } \\
\text { primary industry }\end{array}$ & $\begin{array}{c}\text { Industrial added } \\
\text { value }\end{array}$ & $\begin{array}{l}\text { Added value of } \\
\text { primary industry }\end{array}$ & $\begin{array}{l}\text { Added value of } \\
\text { primary industry }\end{array}$ & Permanent residents \\
\hline Total water supply & 6 & 4 & 3 & 2 & 4 \\
\hline $\begin{array}{l}\text { Water consumption per } \\
\text { capita }\end{array}$ & 7 & 3 & 4 & 3 & 5 \\
\hline $\begin{array}{l}\text { Agricultural water } \\
\text { consumption }\end{array}$ & 1 & 5 & 6 & 5 & 1 \\
\hline $\begin{array}{l}\text { Industrial water } \\
\text { consumption }\end{array}$ & 2 & 7 & 7 & 7 & 3 \\
\hline $\begin{array}{l}\text { Domestic water } \\
\text { consumption }\end{array}$ & 3 & 1 & 1 & 4 & 6 \\
\hline $\begin{array}{l}\text { Ecological water } \\
\text { consumption }\end{array}$ & 4 & 2 & 2 & 1 & 2 \\
\hline $\begin{array}{l}\text { Water resources per } \\
\text { capita }\end{array}$ & 5 & 6 & 5 & 6 & 7 \\
\hline
\end{tabular}

Remark. The order is the grey relational entropy and the entropy values are arranged in descending order.

TABLE 8: Grey relational entropy sorting between the Tianjin water resources system and economic system.

\begin{tabular}{|c|c|c|c|c|c|}
\hline & $\begin{array}{l}\text { Added value of } \\
\text { primary industry }\end{array}$ & $\begin{array}{l}\text { Industrial added } \\
\text { value }\end{array}$ & $\begin{array}{l}\text { Added value of } \\
\text { primary industry }\end{array}$ & $\begin{array}{l}\text { Added value of } \\
\text { primary industry }\end{array}$ & Permanent residents \\
\hline Total water supply & 5 & 5 & 5 & 4 & 1 \\
\hline $\begin{array}{l}\text { Water consumption per } \\
\text { capita }\end{array}$ & 2 & 4 & 3 & 5 & 2 \\
\hline $\begin{array}{l}\text { Agricultural water } \\
\text { consumption }\end{array}$ & 4 & 3 & 1 & 3 & 6 \\
\hline $\begin{array}{l}\text { Industrial water } \\
\text { consumption }\end{array}$ & 7 & 7 & 6 & 6 & 3 \\
\hline $\begin{array}{l}\text { Domestic water } \\
\text { consumption }\end{array}$ & 3 & 6 & 2 & 7 & 5 \\
\hline $\begin{array}{l}\text { Ecological water } \\
\text { consumption }\end{array}$ & 1 & 2 & 7 & 2 & 4 \\
\hline $\begin{array}{l}\text { Water resources per } \\
\text { capita }\end{array}$ & 6 & 1 & 4 & 1 & 7 \\
\hline
\end{tabular}

Remark. The order is the grey relational entropy and the entropy values are arranged in descending order.

TABLE 9: Grey relational entropy sorting between the Hebei water resources system and economic system.

\begin{tabular}{|c|c|c|c|c|c|}
\hline & $\begin{array}{l}\text { Added value of } \\
\text { primary industry }\end{array}$ & $\begin{array}{c}\text { Industrial added } \\
\text { value }\end{array}$ & $\begin{array}{l}\text { Added value of } \\
\text { primary industry }\end{array}$ & $\begin{array}{l}\text { Added value of } \\
\text { primary industry }\end{array}$ & Permanent residents \\
\hline Total water supply & 5 & 5 & 5 & 4 & 1 \\
\hline $\begin{array}{l}\text { Water consumption per } \\
\text { capita }\end{array}$ & 2 & 4 & 3 & 5 & 2 \\
\hline $\begin{array}{l}\text { Agricultural water } \\
\text { consumption }\end{array}$ & 4 & 3 & 1 & 3 & 6 \\
\hline $\begin{array}{l}\text { Industrial water } \\
\text { consumption }\end{array}$ & 7 & 7 & 6 & 6 & 3 \\
\hline $\begin{array}{l}\text { Domestic water } \\
\text { consumption }\end{array}$ & 3 & 6 & 2 & 7 & 5 \\
\hline $\begin{array}{l}\text { Ecological water } \\
\text { consumption }\end{array}$ & 1 & 2 & 7 & 2 & 4 \\
\hline $\begin{array}{l}\text { Water resources per } \\
\text { capita }\end{array}$ & 6 & 1 & 4 & 1 & 7 \\
\hline
\end{tabular}

Remark. The order is the grey relational entropy and the entropy values are arranged in descending order.

5.3.2. Prediction of Entropy. In this paper, the optimal order is selected by the particle swarm algorithm, and then the $\operatorname{FGM}(1,1)$ is used to predict the grey entropy value of the economic system and water resources system in the BeijingTianjin-Hebei region. The results of the optimal order and
MAPE value calculated by the particle swarm are shown in Table 13, and the detailed prediction data are shown in the following.

Judging from the change in entropy in Beijing from 2015 to 2024, Figure 4 shows a downward trend as a whole. The 
TABLE 10: Entropy of grey relational entropy in Beijing from 2015 to 2019.

\begin{tabular}{cccccc}
\hline & $\begin{array}{c}\text { Added value of primary } \\
\text { industry }\end{array}$ & $\begin{array}{c}\text { Industrial added } \\
\text { value }\end{array}$ & $\begin{array}{c}\text { Added value of construction } \\
\text { industry }\end{array}$ & $\begin{array}{c}\text { Added value of tertiary } \\
\text { industry }\end{array}$ & Permanent residents \\
\hline 2015 & 1.994109 & 2.216227 & 2.236412 & 2.225087 & 2.105448 \\
2016 & 2.171178 & 2.06323 & 2.163 & 2.15367 & 2.232031 \\
2017 & 2.366782 & 2.396382 & 2.347595 & 2.348301 & 2.209208 \\
2018 & 2.286548 & 2.07389 & 2.074179 & 2.158283 & 2.267076 \\
2019 & 2.099571 & 2.172422 & 2.137178 & 2.128834 & 2.205361 \\
\hline
\end{tabular}

TABLE 11: Entropy of grey relational entropy in Tianjin from 2015 to 2019.

\begin{tabular}{cccccc}
\hline & $\begin{array}{c}\text { Added value of primary } \\
\text { industry }\end{array}$ & $\begin{array}{c}\text { Industrial added } \\
\text { value }\end{array}$ & $\begin{array}{c}\text { Added value of construction } \\
\text { industry }\end{array}$ & $\begin{array}{c}\text { Added value of tertiary } \\
\text { industry }\end{array}$ & Permanent residents \\
\hline 2015 & 2.190109 & 1.977309 & 2.107581 & 2.281491 & 2.210438 \\
2016 & 2.397745 & 2.287895 & 2.324098 & 2.260918 & 2.043375 \\
2017 & 2.173411 & 2.212023 & 2.423164 & 2.181772 & 2.274511 \\
2018 & 2.133206 & 2.310803 & 1.980684 & 2.295257 & 2.225365 \\
2019 & 2.21116 & 1.979191 & 2.153381 & 1.880452 & 2.197892 \\
\hline
\end{tabular}

Table 12: Entropy of grey relational entropy in Hebei Province from 2015 to 2019.

\begin{tabular}{cccccc}
\hline & $\begin{array}{c}\text { Added value of primary } \\
\text { industry }\end{array}$ & $\begin{array}{c}\text { Industrial added } \\
\text { value }\end{array}$ & $\begin{array}{c}\text { Added value of construction } \\
\text { industry }\end{array}$ & $\begin{array}{c}\text { Added value of tertiary } \\
\text { industry }\end{array}$ & Permanent residents \\
\hline 2015 & 2.188543 & 2.164845 & 2.117012 & 2.117022 & 2.120858 \\
2016 & 2.173659 & 2.278185 & 2.272182 & 2.282682 & 2.300403 \\
2017 & 2.272603 & 2.00645 & 2.313128 & 2.327683 & 2.311867 \\
2018 & 2.321477 & 2.069054 & 2.078969 & 2.194712 & 2.191002 \\
2019 & 1.946381 & 2.370896 & 2.153577 & 1.998694 & 2.00184 \\
\hline
\end{tabular}

TABLE 13: Results of particle swarm optimization in the Beijing-Tianjin-Hebei region.

\begin{tabular}{lccc}
\hline Region & Evaluation index & Optimal order & MAPE (\%) \\
\hline & Added value of primary industry & 0.533632 & 2.539866 \\
Beijing & Industrial added value & 0.21127 & 4.695975 \\
& Added value of construction industry & 0.021358 & 3.142181 \\
& Added value of tertiary industry & 0.54817 & 2.288903 \\
& Permanent residents & 1 & 0.895587 \\
\hline Tianjin & Added value of primary industry & 0.065177 & 2.975361 \\
& Industrial added value & 0.7779 & 2.963154 \\
& Added value of construction industry & 0.180058 & 4.997532 \\
& Added value of tertiary industry & 0.447971 & 3.738722 \\
Hebei & Permanent residents & 0.62491 & 2.018795 \\
& Added value of primary industry & 0.566244 & 4.127879 \\
& Industrial added value & 0.116851 & 4.524057 \\
& Added value of construction industry & 0.886116 & 2.578524 \\
Added value of tertiary industry & 0.551037 & 1.230012 \\
& Permanent residents & 0.552977 & 0.786934 \\
\hline
\end{tabular}

value of grey relation entropy represents the strength of coordination; the larger the value, the stronger the coordination. The value added of the primary industry, the added value of the industrial construction industry, other economic system indicators, and the associated entropy value of the water resources system are decreasing year by year, indicating that the coordination between the two systems is getting worse and worse.

Judging from the change in entropy value of Tianjin from 2015 to 2024 in Figure 5, the overall trend is declining, indicating that the coordination between Tianjin's economic system indicators and water resources system has also become worse and worse.

Judging from the changes in entropy in Hebei Province from 2015 to 2024 in Figure 6, the entropy values of the four indicators of primary industry added value, construction industry added value, tertiary industry added value, and permanent population have decreased year by year. The degree of coordination between each indicator and the water resources system is getting lower and lower. However, it can 

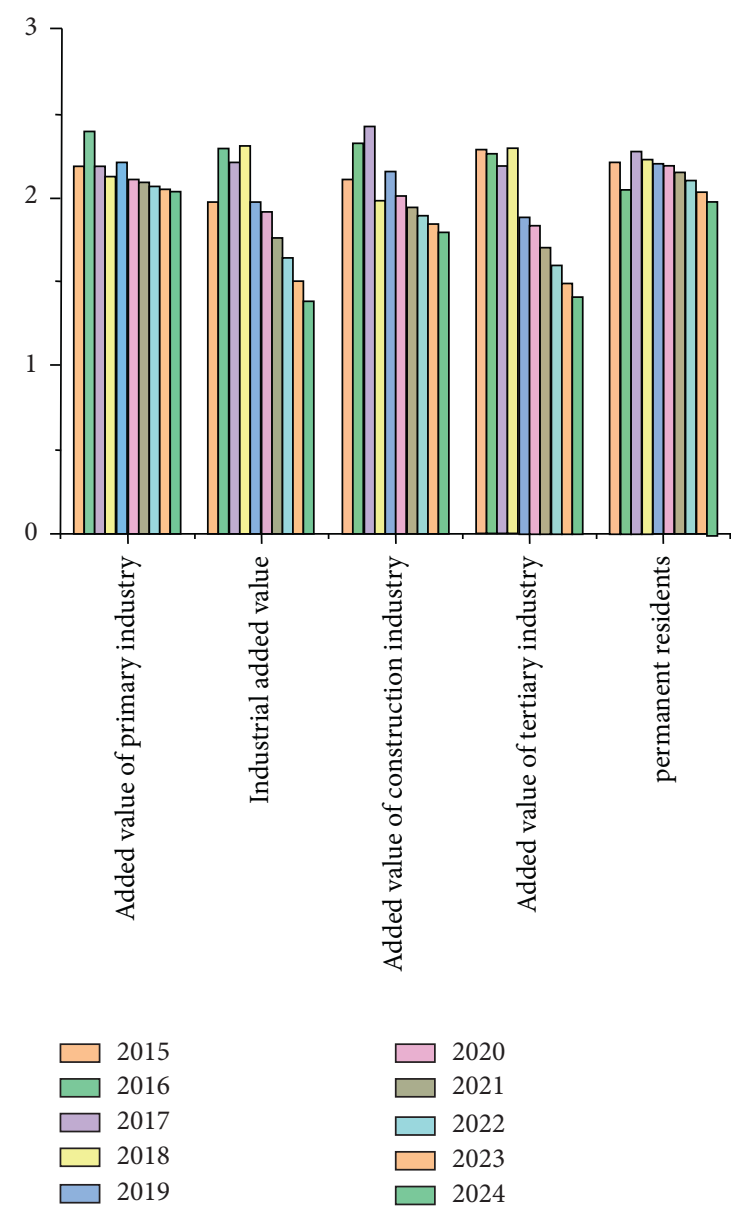

FIGURE 4: Changes in the grey entropy value of Beijing economic system indicators.

be seen from Figure 6 that the industrial added value has been increasing over time, indicating that the industrial added value and the water resources system are more and more closely linked.

5.3.3. Calculation of Entropy Change. From Table 14, the entropy change value of Beijing from 2015 to 2024 shows that the entropy change value of the overall economic system has changed from positive to negative, indicating that the two systems are developing in a healthy and orderly direction. However, comparing the entropy change value in 2023 with the entropy change value in 2024, it is found that the entropy change value has a tendency to change from a negative value to a positive value.

From Table 15 Tianjin's entropy change value from 2015 to 2024 , it can be seen that the entropy change value of the overall economic system has changed from positive to negative, indicating that the two systems are developing in a healthy and orderly direction. However, from the entropy change of added value of primary industry, industrial added value, construction industry, and tertiary industry in 2022, it shows a trend of development from negative to positive and disorderly.

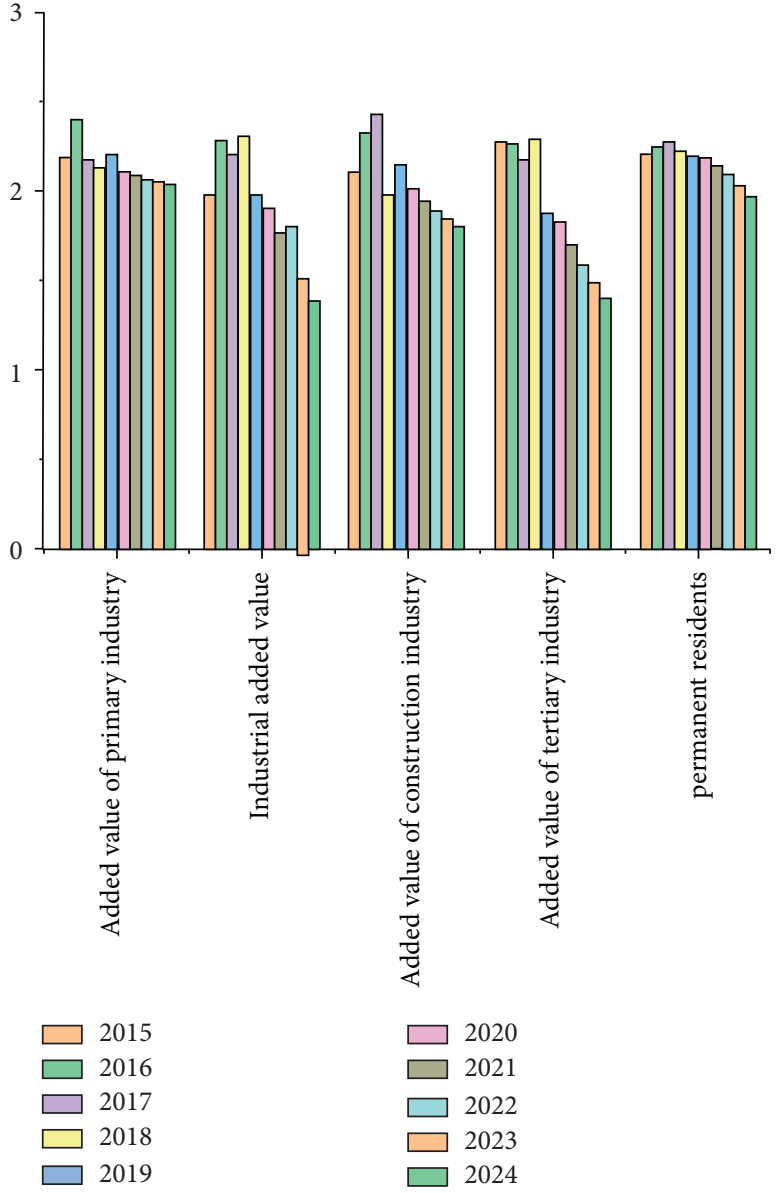

Figure 5: Changes of grey entropy value of Tianjin economic system index.

According to the entropy change value of Hebei Province from 2015 to 2024 in Table 16, the value of the entropy change of the industrial value added has been positive and the value has been increasing in a positive direction. Although other economic system indicators have changed from positive to negative, they will change from 2023 to 2024. In terms of entropy change in recent years, it tends to become positive.

In short, the correlation between water resources and economic systems in the Beijing-Tianjin-Hebei region is not very close to many problems. Although the entropy value continues to decrease and the coordination degree shows a decreasing trend, the entropy change reflects a kind of as long as reasonable improvement methods and strategies are proposed, the closeness between the two systems will be significantly improved, so as to achieve the good development of the Beijing-Tianjin-Hebei region.

\section{Research Implications and Limitations}

6.1. Research Implications. The "13th Five-Year Plan" emphasizes the strengthening of dual control actions and the implementation of the most stringent water resources management system. Water determines production, and water determines cities. By promoting the strategic 


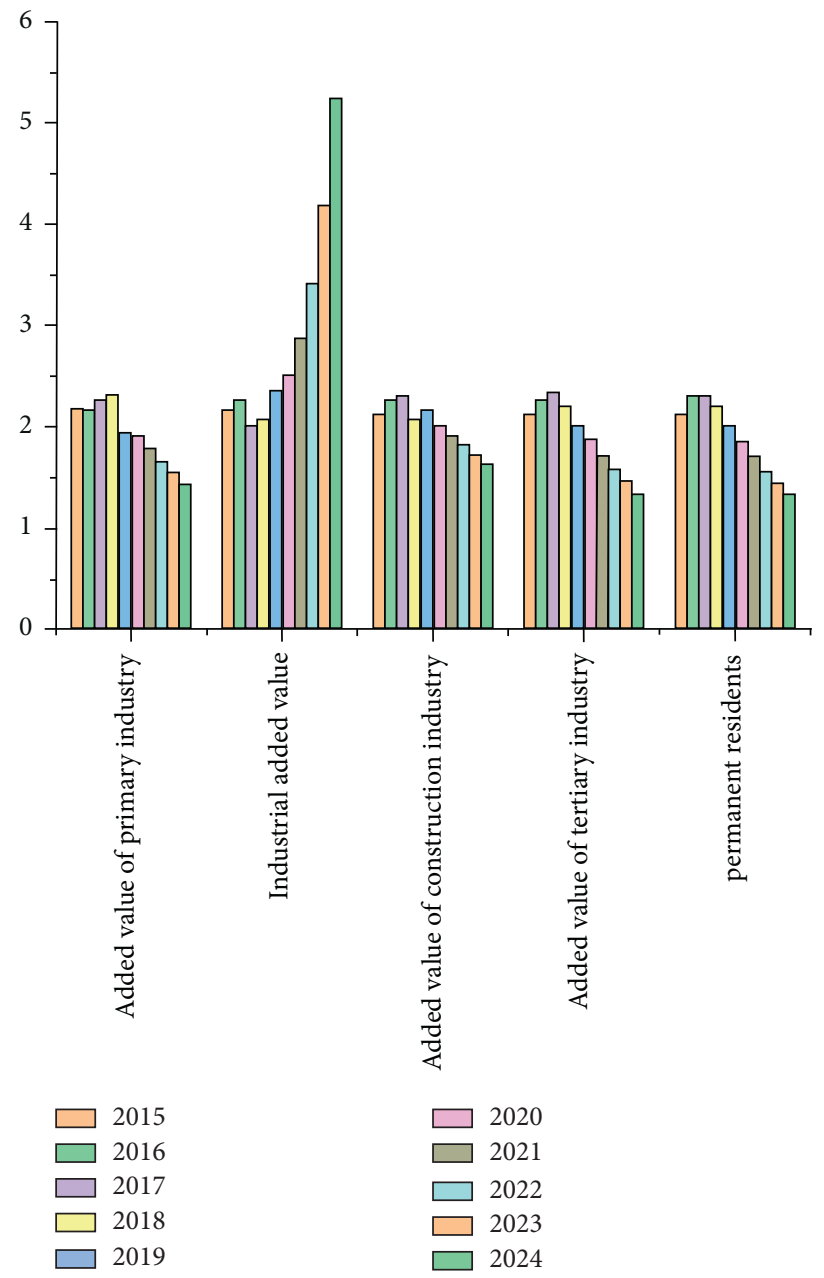

Figure 6: Change of grey entropy of Hebei Province economic system index.

TABLe 14: Entropy change in Beijing from 2015 to 2024.

\begin{tabular}{cccccc}
\hline Year & $\begin{array}{c}\text { Added value of primary } \\
\text { industry }\end{array}$ & $\begin{array}{c}\text { Industrial added } \\
\text { value }\end{array}$ & $\begin{array}{c}\text { Added value of construction } \\
\text { industry }\end{array}$ & $\begin{array}{c}\text { Added value of tertiary } \\
\text { industry }\end{array}$ & Permanent residents \\
\hline 2015 & & & & & \\
2016 & 0.177069 & -0.153 & -0.07341 & -0.07142 & 0.126583 \\
2017 & 0.195605 & 0.333152 & 0.184595 & -194631 & -0.02282 \\
2018 & -0.08023 & -0.32249 & -0.27342 & -0.19002 & -0.057868 \\
2019 & -0.18698 & 0.098532 & 0.062999 & -0.02945 & -0.06172 \\
2020 & -0.07314 & -0.02462 & -0.00943 & -0.09174 & -0.017547 \\
2021 & -0.11984 & -0.03264 & -0.00788 & -0.10156 & -0.0022 \\
2022 & -0.11656 & -0.03691 & -0.00677 & -0.10324 & -0.0022 \\
2023 & -0.10928 & -0.03857 & -0.00594 & -0.10077 & -0.00219 \\
2024 & -0.10029 & -0.03856 & -0.0053 & -0.09595 & \\
\hline
\end{tabular}

transformation of my country's economic and social development mode, we can achieve economic growth while reducing water consumption. Therefore, the rational deployment between the water resources system and the economic system plays an important role in the future development of the Beijing-Tianjin-Hebei region.

Beijing-Tianjin-Hebei region has proposed many effective methods for reducing water use, such as water saving and the use of reclaimed water. However, few scholars can rationally allocate water resources from different types of industries, as far as possible to achieve a balance between industrial needs and water supply, so as to reduce water waste. Therefore, this paper calculates the grey relational entropy value and grey relational entropy difference between water resources and economic systems, which can not only provide suggestions for the rational allocation of water 
TABLe 15: Entropy change in Tianjin from 2015 to 2024.

\begin{tabular}{cccccc}
\hline Year & $\begin{array}{c}\text { Added value of primary } \\
\text { industry }\end{array}$ & $\begin{array}{c}\text { Industrial added } \\
\text { value }\end{array}$ & $\begin{array}{c}\text { Added value of construction } \\
\text { industry }\end{array}$ & $\begin{array}{c}\text { Added value of tertiary } \\
\text { industry }\end{array}$ & Permanent residents \\
\hline 2015 & & & & & \\
2016 & 0.207636 & 0.310586 & 0.216517 & -0.02057 & -0.16706 \\
2017 & -0.22433 & -0.07587 & 0.099066 & -0.07915 & 0.231136 \\
2018 & -0.04021 & 0.09878 & -0.44248 & 0.113485 & -0.04915 \\
2019 & 0.077954 & -0.33161 & 0.172697 & -0.41481 & -0.02747 \\
2020 & -0.09862 & -0.07456 & -0.14452 & -0.0488 & -0.00537 \\
2021 & -0.02349 & -0.1383 & -0.06556 & -0.12694 & -0.04316 \\
2022 & -0.01983 & -0.13337 & -0.05468 & -0.114 & -0.05419 \\
2023 & -0.01714 & -0.12588 & -0.04624 & -0.10046 & -0.06117 \\
2024 & -0.01508 & -0.11722 & -0.03975 & -0.08775 & \\
\hline
\end{tabular}

TABle 16: Entropy change in Hebei from 2015 to 2024.

\begin{tabular}{cccccc}
\hline Year & $\begin{array}{c}\text { Added value of primary } \\
\text { industry }\end{array}$ & $\begin{array}{c}\text { Industrial added } \\
\text { value }\end{array}$ & $\begin{array}{c}\text { Added value of construction } \\
\text { industry }\end{array}$ & $\begin{array}{c}\text { Added value of tertiary } \\
\text { industry }\end{array}$ & Permanent residents \\
\hline 2015 & & & & & \\
2016 & -0.01488 & 0.11334 & 0.15517 & 0.16566 & 0.179545 \\
2017 & 0.098944 & -0.27174 & 0.040946 & 0.045001 & 0.011464 \\
2018 & 0.048874 & 0.062604 & -0.23416 & -0.13297 & -0.12087 \\
2019 & -0.3751 & 0.301842 & 0.074608 & -0.19602 & -0.18916 \\
2020 & -0.03091 & 0.139241 & -0.14122 & -0.13495 & -0.14486 \\
2021 & -0.12803 & 0.375373 & -0.09356 & -0.14819 & -0.14978 \\
2022 & -0.12262 & 0.537652 & -0.09356 & -0.13559 & -0.13661 \\
2023 & -0.11409 & 0.759968 & -0.09193 & -0.12122 & -0.12181 \\
2024 & -0.10429 & 1.066624 & -0.08932 & -0.10698 & -0.10725 \\
\hline
\end{tabular}

resources in the future but also can rationally plan the industrial structure in the economic system based on the water resources in different regions.

6.2. Research Limitations. This study has some limitations [31]. First of all, based on the requirements of industrial adjustment, the phenomenon of manufacturing agglomeration has appeared in Hebei Province [31], and the impact of industrial activity concentration on water resources is not considered in this article. In future research, we will consider the impact of industrial concentration on the rational allocation of water resources and the impact of industrial agglomeration on the allocation of water for other industries. Secondly, the division of the Beijing-Tianjin-Hebei region is not very detailed, it is not divided according to the city or the area in the city, and there are no water supply and water plan for each city or area in the city. Future research can be more detailed and comprehensive, so that the research results are more in line with the characteristics of each place.

\section{Conclusion}

This paper constructs a water resource system (total water supply, per capita water consumption, agricultural water consumption, industrial water consumption, domestic water consumption, ecological water consumption, and per capita water resources) and economic system (primary industry added value, industrial added value, the added value of the construction industry, the added value of the tertiary industry, and the permanent population). A grey relational entropy model is used to calculate the entropy value between the water-economic systems, and then the entropy difference is calculated to determine the future development relationship between the two systems.

For the Beijing-Tianjin-Hebei region, most of them have studied the grey relationship between economy and environment, the grey relationship between environment and water resources, and the relationship between economy and energy. However, the relationship between economy and water resources is ignored by most people, and there are few studies on the relationship between economic indicators and water resources indicators. The results show that the grey correlation between the total water supply and economic indicators is very low (only about 0.4-0.5). However, the entropy difference changes from positive to negative, indicating that the relationship between the two systems is developing in a healthy and orderly direction. This change shows that some scholars are currently preparing to conduct research on water conservation from the perspective of industrial classification and deploy water supply plans. This initiative is in line with the proposed water-saving policy.

It is found through research that the entropy value between the industrial added value in the economic system and the industrial water consumption in the water resources system is very low, indicating that the government's watersaving plan does not start from the industrial point of view. The relationship between the number of local residents and per capita water consumption is poor, so residents can start 
by themselves to advocate effective water-saving programs such as "one water" for multiple uses. From the perspective of enterprises, they should actively predict their own water use and future water use and at the same time enhance the water-saving effect of equipment. The three parties work together to turn limited resources into unlimited gains.

This paper proposes that the correlation between water resources and economic systems just complements the link between economic benefits and the rational use of water resources. It is necessary to ensure rapid economic development while at the same time ensure the minimal use of resources. Using this grey relational evaluation method can effectively allocate water for different industries. This method can not only reduce the material and financial resources of irrational allocation of water resources but also reduce the waste of water resources from the source. More importantly, this method enriches the diversity of watersaving measures and can also reduce the waste of water resources on the premise of ensuring continuous economic development.

\section{Data Availability}

The data used to support the findings of this study are available from the corresponding author upon request.

\section{Conflicts of Interest}

The authors declare that they have no conflicts of interest.

\section{Acknowledgments}

This study was supported by the National Natural Science Foundation of China (71871084 and U20A20316), the Excellent Young Scientist Foundation of Hebei Education Department (SLRC2019001), the Natural Science Foundation of Hebei Province (E2020402074), and the Social Science Federation Project of Handan (2021058 and 2021077).

\section{References}

[1] X. Duan, Research on Water Resources Planning in Mountainous Cities Based on Ecological Concepts, Chongqing University, Chongqing, China, 2015.

[2] W. Wang, Research on the Construction of a Water-Saving Society in Dalian from the Perspective of Sustainable Development, Dalian Maritime University, Dalian, China, 2012.

[3] X. Wang, "Do not forget the original intention of struggle, keep in mind the mission of water affairs, and write a new chapter in the reform and development of Langfang water conservancy," Hebei Water Resources, vol. 11, p. 10, 2017.

[4] C. Lei, "A scientific guide for water control and rejuvenation in the new era-Deeply study and implement General Secretary Xi Jinping's important exposition on water control," Seeking Truth, vol. 15, no. 15, pp. 47-49, 2014.

[5] D. Xi, X. Xu, D. Han, and Z. Yang, "Evaluation of water resources carrying capacity in the Beijing-Tianjin-Hebei region," Journal of Beijing Normal University, vol. 53, no. 5, pp. 575-581, 2017.
[6] H. Zhao, Research on Legal Issues of Water Pollution Prevention and Control in Beijing-Tianjin-Hebei Countryside, Hebei University, Baoding, China, 2019.

[7] W. Dongtao, X. Liu, G. Ding, and Y. Chen, "Complicated equipment cost estimation model based on entropy theory," Journal of Beijing University of Aeronautics and Astronautics, vol. 47, pp. 1-10, 2021.

[8] H. Li, H. Guo, and Y. Zhang, "Grey relational entropy analysis of the influence of cement-based concrete pore structure evolution characteristics on strength Building," Structure, vol. 50, no. 24, pp. 116-123, 2020.

[9] X. Chen and X. Yang, "The influence of the development of digital economy on the upgrading of industrial structure--A study based on the grey relation entropy and the theory of dissipative structure," Reform, vol. 325, no. 3, pp. 26-39, 2021.

[10] H. Zhao, X. Sun, Q. Xu, Y. Hu, Z. Sun, and W. Li, “Analysis of correlation factors between highway freight volume and cargo turnover based on grey entropy method," Journal of Traffic and Transportation Engineering, vol. 18, no. 4, pp. 160-170, 2018.

[11] X. Zhang, H. Sipeng, J. Li, and C. Jiang, "Analysis of influencing factors of wind turbine MPPT control based on grey correlation," Power System Technology, vol. 39, no. 2, pp. 445-449, 2015.

[12] S. Zhu, S. Chen, X. Qin, and Z. Li, "Key indicators of highviscosity modified asphalt based on grey relation entropy analysis method," Journal of Materials Science and Engineering, vol. 32, no. 6, pp. 863-867, 2014.

[13] L. Xi, K. Jiang, and B. Zheng, "Research on the order of emerging industries and the optimization and upgrading of China's industrial structure," Science of Science and Management of Science and Technology, vol. 31, no. 12, pp. 115-121, 2010.

[14] K. He, "Analysis of the driving factors of PM2.5 in henan province based on grey correlation model," World Scientific Research Journal, vol. 7, no. 5, 2021.

[15] L. Yin, L. Duan, Y. Zhang, H. Liu, C. Zhang, and Q. Sun, “The investigation and analysis of the current situation of medical service price cognition of China with grey relational analysis theory," Grey Systems: Theory and Application, vol. 9, no. 2, 2019.

[16] M. Liu, Y. Zhang, W. Dong, Z. Yu, and L. Sifeng, "Grey modeling for thermal spray processing parameter analysis," Grey Systems: Theory and Application, vol. 10, no. 3, 2020.

[17] J. Shen, S. Shi, Y. Zhou, Y. Zhang, and Z. Yao, "Surface water environmental quality assessment of Danjiangkou Basin based on improved grey correlation analysis method," China Environmental Monitoring, vol. 30, no. 5, pp. 41-46, 2014.

[18] Y. Wang, H. Wang, and X. Wang, "A method for identifying voltage sag sources based on improved grey relational analysis," Electrical Measurement \& Instrumentation, vol. 57, no. 15, pp. 1-7, 2020.

[19] S. Liu, Y. Yang, and L. Wu, Grey System Theory and its Application, pp. 1-3, Science Press, Beijing, China, 2014.

[20] L. Wu, S. Liu, L. Yao, S. Yan, and D. Liu, "Grey system model with the fractional order accumulation," Communications in Nonlinear Science and Numerical Simulation, vol. 18, no. 7, pp. 1775-1785, 2013.

[21] W. Meng and B. Zeng, "Discrete grey model and order optimization based on reciprocal fractional-order operators," Control and Decision, vol. 31, no. 10, pp. 1903-1907, 2016.

[22] X. Meng, F. Fan, and L. Wu, "Prediction of major pollutants discharge from wastewater in 31 cities of China," Sustainable Production and Consumption, vol. 26, pp. 54-64, 2021. 
[23] J. Cui, S. Liu, B. Zeng, and N. Xie, "A novel grey forecasting model and its optimization," Applied Mathematical Modelling, vol. 37, no. 6, 2013.

[24] L. Wu and H. Zhao, "Using FGM(1,1) model to predict the number of the lightly polluted day in Jing-Jin-Ji region of China," Atmospheric Pollution Research, vol. 10, no. 2, 2018.

[25] L. Wu, N. Li, and Y. Yang, "Prediction of air quality indicators for the Beijing-Tianjin-Hebei region," Journal of Cleaner Production, vol. 196, 2018.

[26] C. Li, X. Gao, J. Wu, and K. Wu, "Demand prediction and regulation zoning of urban-industrial land: evidence from Beijing-Tianjin-Hebei Urban Agglomeration, China," Environmental Monitoring and Assessment, vol. 191, no. 7, 2019.

[27] B.-J. He, J. Wang, H. Liu, and U. Giulia, "Localized synergies between heat waves and urban heat islands: implications on human thermal comfort and urban heat management," Environmental Research, vol. 193, 2021.

[28] N. Zhao and J. Deng, "Overview of particle swarm optimization algorithms," Science and Technology Innovation Herald, vol. 12, no. 26, pp. 216-217, 2015.

[29] S. Milad, R. Abdolreza, and F. Sadegh, "Particle distance rank feature selection by particle swarm optimization," Expert Systems with Applications, vol. 185, 2021.

[30] G. Nipun, K. L. Kam, and P. Eric, "Particle swarm optimization for source localization in realistic complex urban environments," Atmospheric Environment, vol. 262, 2021.

[31] C. Li, X. Gao, B.-J. He, J. Wu, and K. Wu, "Coupling coordination relationships between urban-industrial land use efficiency and accessibility of highway networks: evidence from Beijing-Tianjin-Hebei urban agglomeration, China," Sustainability, vol. 11, no. 5, p. 1446, 2019.

[32] X. Wu and C. Zhang, "Research on the coordination of my country's postal industry and economic development-based on grey entropy correlation model," Journal of Beijing University of Posts and Telecommunications, vol. 15, no. 1, pp. 77-81, 2013.

[33] M. Guo, "Research on the relationship between ICT industry and industrial structure optimization and upgrading-analysis based on grey relation entropy model," Inquiry into Economic Issues, no. 4, pp. 131-140, 2019.

[34] N. Li, Fractional Cumulative Grey Model and its Application in Air Quality Prediction, Vol. 17, Hebei University of Engineering, Handan, China, 2020. 